\title{
The Effect of Profitability Ratio, Liquidity Ratio, Leverage Ratio, and Company Size on Sukuk Rating Corporation During 2014-2017 Periods
}

\author{
Suratmi $^{1^{*}}$, Ika Yustina Rahmawati ${ }^{2}$ \\ ${ }^{1}$ Economics and Business Faculty, Universitas Muhammadiyah Purwokerto \\ ${ }^{2}$ Economics and Business Faculty, Universitas Muhammadiyah Purwokerto
}

\begin{abstract}
The purpose of this study was to destermine the effect of profitability ratios, liquidity ratios, leverage ratios, and company size toward sukuk ratings in Indonesia during 2014-2017. The independent variables in this study is profitability ratios, liquidity ratios, leverage ratios, and company size, while the dependent variable is sukuk rating. The object of this study is Corporations for the period 2014-2017, this study used 78 samples. The technique sampling method in this study used purposive sampling. The data analysis techniques used in this study is descriptive statistical tests, and logistic regression tests. The results of the analysis show that simultaneously profitability ratios, liquidity ratios, leverage ratios and company size have a significant effect on sukuk ratings. Partially the size of the company has a significant positive effect on the sukuk rating, while the profitability ratio, liquidity ratio, and leverage ratio have no significant positive effect on the sukuk rating.
\end{abstract}

\section{Introduction}

The development of the Islamic capital market is characterized by various indicators including the increasingly widespread sharia capital market players that issue sharia securities in addition to stocks in the Jakarta Islamic Index (JII). Sharia securities that can be traded in the Islamic capital market, one of which is sharia bonds, now known as sukuk (Nurhayati and Wasiah, 2105). Islamic bonds (sukuk) in accordance with the Fatwa of the National Sharia Council No.32 / DSN-MUI / IX / 2002 are long-term securities based on sharia principles issued by issuers to holders of Islamic bonds that require issuers to pay income to sharia bond holders in the form of yield / margin / fee and repay and bond at maturity.

Sharia Capital Market Statistics issued by Otoritas Jasa Keuangan (OJK) in 2015 stated that based on total value and total sukuk emissions and outstanding sukuk show a significant number from year to year where at the beginning of 2010 the total value of sukuk emissions reached 7,815.00 billion later increased in 2015 to $14,483.00$ billion. This is in line with the value of outstanding sukuk, where in 2010 the achievement of outstanding sukuk was $6,121.00$ billion and then increased in 2015 to $8,444.40$ billion

* Corresponding author: arlinta@ del.ac.id 
rupiahs. Even though in several years the outstanding sukuk had experienced a decline, as in 2011 and in 2014, but in the years after the outstanding sukuk conditions continued to increase (https://analisis-perkembangan-sukuk-di-indonesia/).

In general, bonds are divided into two ratings, namely Investment Grade (Bonds that ratings fall into the top four rating categories) and non-investment grade (Bonds that rating is not included in the four top rating categories). The grade improvement has AAA, AA, A, and $\mathrm{BBB}$ ratings. Whereas for non-investment grade with $\mathrm{BB}, \mathrm{B}, \mathrm{CCC}$, and $\mathrm{D}$. The main purpose of the bond rating is to provide accurate information about financial performance, industrial business position, the company that issues bonds (bonds) in the form of ratings to investors. Investors who are interested in buying bonds should pay attention to bond ratings because the bond rating gives a signal about the probability of a company's failure to pay interest and principal loans. Sudana (2009: 127) stated that one of the considerations of investors in choosing bonds issued by various companies is information about bond ratings. In Indonesia there are three rating agencies namely PT. PEFINDO (Rating Agency of Indonesia), Fitch Indonesia and ICRA.

Brigham and Houstan (2012) stated that the factors that influence bond ratings consist of qualitative and quantitative factors. One of the quantitative factors is financial ratios. A good bond rating is reflected in the company's financial statements, where if the company's performance improves, the rating will increase so investors are interested in investing (Sihombing and Rahmawati, 2015). One way to measure company performance in sukuk rating is profitability, liquidity, leverage, and company size.

\section{Literature Review}

Signaling theory explains why companies provide capital market information. This theory suggests the importance of companies on giving signals to interested parties or potential investors is the issuance of financial statements by the company. This is done to convey the condition of the company to the wider community because through the delivery of information it can convince the public to invest their capital in the company. One positive signal given by the company to attract potential investors is the bond rating. Bond rating provide information on the security of bonds issued by the company.

According to the Fatwa Majelis Ulama Indonesia No.31 / DSN-MUI / IX / 2002 sukuk is a long term securities based on sharia principles issued by issuers to holders of Islamic bonds. Sukuk requires issuers to pay income to holders of Islamic bonds in the form of profit sharing margin/fee, as well as paying back the bond funds at maturity.

Some of the measurements used are: (1) profitability ratio is this ratio measures the overall effectiveness of management as shown by the size of the level of profits obtained in relation to sales and investment. (2) Liquidity is the ability of a company to fulfill its shortterm obligations in a timely manner. A high level of risk indicates that the company has the ability to pay for all its current liabilities and shows the strong financial condition of the company. (3) Leverage is measuring how much the company is financed by debt. The use of debt that is too high will endanger the company because the company will be in the category of extreme leverage, namely the company is caught in a high debt level and it is difficult to release the debt burden. (4) The size of the company is a scale that classifies the size of the company that is related to financial companies (Juliantari and Rasmini, 2013). Company size is the size of the company that can be measured by total assets or sales (Sartono, 2010: 128).

The framework for the formation of hypotheses is as follows: 


\subsection{The Effect of Profitability on Sukuk Ratings.}

The influence of profitability on sukuk ratings according to Mardiah et al. (2016) stated that profitability has a significant effect on sukuk ratings, Kurniawan et al. (2017) stated that profitability has a significant positive effect on sukuk ratings, Tensia et al. (2015) stated that profitability has a significant positive effect on bond ratings, Praptiningisih (2015) stated that profitability has a significant effect on bond ratings, Astuti (2017) stated that profitability has a significant positive effect on sukuk ratings. Pebruari (2016) stated that profitability has a significant positive effect on sukuk rating, the high or low value of profitability or profitability of a company will affect the sukuk rating. This gives rise to the hypothesis:

H1: partially profitability variable has a positive and significant effect on sukuk ratings.

\subsection{The Effect of Liquidity on Sukuk Ratings.}

Liquidity according to Mardiah et al. (2016), liquidity ratios have a significant effect on sukuk ratings, Kustiyaningrum et al. (2016) stated that liquidity has an effect on bond ratings, Ma'arij (2014) proved that liquidity has a significant effect on bond ratings, Praptiningsih (2015) stated that liquidity ratios have a significant effect towards bond ratings, Astuti (2017) stated that liquidity has a significant positive effect on sukuk ratings, and Pebruari (2016) stated that liquidity has a significant positive effect on sukuk ratings. The higher the liquidity ratio means the greater the company's ability to fulfill short-term financial obligations. Then the second hypothesis is:

H2: Partially liquidity variables have a positive and significant effect on sukuk ratings.

\subsection{The Effect of Leverage on Sukuk Ratings.}

Leverage in the study of Mardiah et al (2016) stated that leverage has a significant effect on sukuk rankings, Kurniawan et al (2017) stated that leverage has a significant negative effect on sukuk ratings, Tensia et al (2015) stated that leverage has a significant negative effect on bond ratings, Pebruary (2016 ) stated that leverage has a significant negative effect on sukuk rating. High leverage describes a company having a high interest expense and this will have an impact on the low ranking of sukuk. Then the third hypothesis is:

H3: Partially the leverage variable has a negative and significant effect on the sukuk ratings.

\subsection{The Effect of Company Size on Sukuk Ratings.}

Ma'arij (2014) stated that company size has a significant effect on bond ratings, Tensia et al. (2015) stated that company size has a positive significant effect on bond ratings, Martinus (2014) stated that company size has an influence on bond ratings, Praptiningsih (2015) stated that company size has a significant effect on bond ratings, and according Sihombing (2015), company size has a significant effect on bond ratings. Company size has a positive direction, meaning if there is an increase in company size, it will increase bond ratings, as well as decreasing company size it will lower the sukuk rating. The fourth hypothesis is formed as follows:

H4: partially company size variables have a positive and significant effect on sukuk ratings. 


\subsection{The Effect of Profitability, Liquidity, Leverage, and Company Size on Sukuk Ratings.}

Praptiningsih (2015) stated that simultaneously profitability, liquidity and company size significantly influence bond ratings, Kurniawan and Suwarti (2017) stated that simultaneously variable Profitability, liquidity and leverage have a significant effect on sukuk ratings., Winanti et al. (2017) stated that simultaneous Profitability and liquidity variables have a significant effect on sukuk ratings, Martinus (2014) stated that company size, debt to equity ratio and current ratio have a significant effect on bond ratings, Kustiyaningrum et al. (2016) stated that profitability, liquidity, leverage and company size have a significant effect on bond ratings, Mardiah et al. (2016) stated that simultaneous liquidity, profitability, and company size influence bond ratings. Astuti (2017) states that simultaneously Liquidity and Profitability have a significant effect on sukuk ratings. Then the fifth hypothesis is formed as follows:

H5: simultaneously variable profitability, liquidity, leverage, and company size have a significant effect on sukuk rating.

\section{Study Method}

This type of study uses quantitative study, with secondary data. The secondary data used are from 2014 untill 2017 which includes the company's fundamental data that issues sukuk in that year. The population in this study are companies that issues sukuk and are rated by PEFINDO. The sample studied is only corporate companies. The sample selection was done by using purposive sampling to obtain 78 data samples from 2014-2017 periods.

\subsection{Data Analysis Method}

Hypothesis testing in this study using logistic regression. This is because the dependent variable in this study is a dummy variable, which is a variable that has two alternatives. Logistic regression is generally used if the assumption of multivariate normal distribution is not fulfilled (Ghozali, 2006 in Pandutama, 2012). This means that the independent variable does not have to have a linear normal distribution or has the same variant in each group. In this study logistic regression was used to test the variables of profitability, liquidity, leverage, and firm size on sukuk ratings. The logistic regression used is as follows (Ghozali, 2011 in Kuswara, 2014):

$$
\text { Ln } \frac{\text { RATING }}{1-\text { RATING }}=\alpha+\beta 1 X 1+\beta 2 X 2+\beta 3 X 3+\beta 4 X 4+e
$$

Ln $\frac{\text { RATING }}{1-R A T I N G}$ : Sukuk Ratings, 1 for sukuk in investment grade rating and 0 for sukuk in non-investment grade rating

$\alpha \quad$ : Constants

$\beta 1-\beta 4$ : Regression Coefficient for each factor

$\mathrm{X} 1$ : Profitabily

X2 : Liquidity

X3 : Leverage

X4 : Company Size

e : Error

\section{Operational Definition of Variables}




\subsection{Dependent Variable (Y)}

Dependent variable in this study is Sukuk Rating. This sukuk rating is a rating given by PT. PEFINDO. Based on the ranking definition issued by PT PEFINDO, AAA, AA, A, and $\mathrm{BBB}$ ratings are included in the investment grade category while $\mathrm{BB}, \mathrm{B}, \mathrm{CCC}$ and $\mathrm{D}$ are included in the non-investment grade category.

The measurement scale used is an ordinal scale, where measurement was made by giving a value of 1 to the investment grade category and a value of 0 to non-investment grade sukuk because the dependent variable in this study is a dummy variable.

\subsection{Independent Variable (X)}

\subsubsection{Profitability Ratio (X1)}

This ratio measures the effectiveness of management as a whole which is shown by the size of the level of profits obtained in relation to sales and investment. Profitability is proxied by Return on Assets (ROA).

$$
R O A=\frac{\text { Total Profit }}{\text { Total Assets }}
$$

\subsubsection{Liquidity Ratio (X2)}

Liquidity is the ability of a company to meet its short-term obligations in a timely manner. Liquidity in this study is proxied by Current Ratio (CR).

$$
C R=\frac{\text { Current Assets }}{\text { Current Liabilities }}
$$

\subsubsection{Leverage Ratio (X3)}

Leverage is measured to know how much a company is financed by debt. The use of debt that is too high will endanger the company because the company will be in the category of extreme leverage, namely the company is caught in a high debt level and it is difficult to release the debt burden. Leverage ratio is proxied by Debt Equity Ratio (DER).

$$
D E R=\frac{\text { Total Liabilities }}{\text { Total Share Holder Equity }}
$$

\subsubsection{Company Size (X4)}

The size of the company is a scale that classifies the size of the company that is related to the financial company.

$$
\text { Company size: Ln total assets }
$$

\section{Results}

\subsection{Descriptive Statistics}

Table 1. Descriptive Statistics Output 


\begin{tabular}{|c|c|c|c|c|c|}
\hline & N & Minimum & Maximum & Mean & Std. Deviation \\
\hline RATING & 78 & 0 & 1 &, 95 &, 222 \\
ROA & 78 &, 00042 &, 11022 &, 0272292 &, 02530688 \\
CR & 78 &, 42299 & 13,95212 & 2,4778474 & 2,38677574 \\
DER & 78 &, 28631 & 9,01184 & 2,9326524 & 2,33465793 \\
SIZE & 78 & 28,88012 & 34,82768 & 31,0070206 & 1,19446212 \\
Valid N & 78 & & & & \\
(listwise) & 78 & & & & \\
\hline
\end{tabular}

\subsection{Assessing the Feasibility of the Regression Model (Model Fit)}

Based on the results of the table, it is known that the significance value or probability of receiving $\mathrm{H} 0$ is 1,000 which indicates a probability value $>0.05$ so that $\mathrm{H} 0$ is accepted or the model can be said to be fit with the data.

\subsection{Assessing the Overall Feasibility of the Model (Overall Model Fit)}

This test is used to assess models that have been hypothesized to be fit or not with data. Based on the data in table 4.6 it is known that the results show a decrease in the value of $2 \log \mathrm{L}$, which is from block number $=0$ of 38,337 to 36,254 on the block number $=1$. Therefore, it can be concluded that the model hypothesized is fit with data so that it can be used for study.

\subsection{Nagelkerke's R Square}

Based on the data in table 2, the value of Nagelkerke's R Square is indicated at 0.499 which means the ability of the independent variable is $49.9 \%$ while the remaining $50.1 \%$ is influenced by other variables not discussed in this study.

\subsection{Regression Coeffiecient}

This study examines the effect of variable profitability, liquidity, leverage and firm size on sukuk ratings. Based on the testing of the regression coefficient in table 2, the logistic equation model is obtained as follows:

Table 2. Regression Coeffisient Output

Variables in the Equation

\begin{tabular}{|c|c|c|c|c|c|c|c|c|c|}
\hline & \multirow[b]{2}{*}{ B } & \multirow[b]{2}{*}{ S.E. } & \multirow[b]{2}{*}{ Wald } & \multirow[b]{2}{*}{ df } & \multirow[b]{2}{*}{ Sig. } & \multirow[b]{2}{*}{$\operatorname{Exp}(B)$} & \multicolumn{2}{|c|}{$95 \%$ C.I.for EXP(B) } \\
\hline & & & & & & & & Lower & Upper \\
\hline & $\mathrm{ROA}$ & $-34,277$ & 24,183 & 2,009 & 1 & ,156 &, 000 &, 000 & 499139,918 \\
\hline & $\mathrm{CR}$ &,- 640 & 613 & 1,088 & 1 & 297 & ,527 & 159 & 1,755 \\
\hline & DER &,- 138 & ,590 &, 055 & 1 & 815 & 871 & 274 & 2,769 \\
\hline & SIZE & 4,603 & 2,179 & 4,463 & 1 & ,035 & 99,736 & 1,394 & 7134,715 \\
\hline & Constant & $-132,282$ & 62,905 & 4,422 & 1 & ,035 & ,000 & & \\
\hline
\end{tabular}

Source: processed data, 2019

$\operatorname{Ln} \frac{\text { RATING }}{1-R A T I N G}=-132,282-34,277$ ROA-0,640CR-0,138DER +4,603SIZE $+\mathrm{e}$

\section{Discussion}




\subsection{First Hyphotesis}

Based on the results of hypothesis testing it can be concluded that profitability partially does not have a significant positive effect on sukuk ratings. This is due to the proportion of the use of profits not used in funding cash flows or short-term debt (bonds) but rather to pay dividends in larger amounts. The results of this study are in accordance with the study of Kustiyaningrm et al. (2016), Winanti et al. (2017), Sihombing and Rachmawati (2015) which stated that profitability does not have a significant positive effect on sukuk ratings.

\subsection{Second Hyphotesis}

Based on the results of hypothesis testing it can be concluded that liquidity partially has no significant positive effect on sukuk ratings. Liquidity is not a consideration in determining bond ratings because the liquidity of each company is different between one company sector and another company sector. This study is in accordance with the study of Kurniawan et al. (2017), Winanti et al. (2017), Martinus and Rosita (2014), Tensia et al. (2015) which stated that liquidity does not have a significant positive effect on sukuk ratings.

\subsection{Third Hyphotesis}

Based on the results of hypothesis testing, it can be concluded that leverage partially has no significant effect on sukuk ratings. This is because some companies in this study have collateral or guaranteed by their parent company so that the sukuk rating is not based on financial ratios but rather from the company that guarantees it. If the company's debt is weak, it will be strengthened by the guarantee company, so that the bond will be given the same rating as the guarantee company. This study is consistent with the study of Kustiyaningrum et al. (2016), Ma'arij (2014), Sihombing and Rachmawati (2015), Martinus and Rosita (2014) stated that leverage does not significantly influence sukuk ratings.

\subsection{Fourth Hyphotesis}

Based on the results of hypothesis testing it can be concluded that the size of the company partially has a significant positive effect on sukuk ratings. Based on these results it can be concluded that investors and other information users can use company size as the basis for determining investment in corporate sukuk. The results of this study are in accordance with Tensia et al. (2015), Praptiningsih (2015), Sihombing (2015), Martinus and Rosita (2014) stated that firm size has a significant positive effect on sukuk ratings.

\subsection{Fifth Hyphotesis}

Based on the results of hypothesis testing it can be concluded that profitability, liquidity, leverage and company size simultaneously have a significant effect on sukuk ratings. This is due to the large liquidity in this study. With high liquidity, it will have an impact on the company's profits. Profit earned is not only used as an operational activity, but rather as payment of dividends and debt financing.

In addition, leverage, liquidity and profitability is one of the financial elements included in PEFINDO's sukuk rating assessment, which is in financial risk. With the existence of good financial risk it is considered less risky in investing so that it will provide a good company rating and the greater the total assets of the company, the greater the size of the company that has more complex operations than smaller companies. 


\section{Conclusions}

Based on study and data analysis, the following conclusions can be drawn. First, partially Profitability does not have a significant positive effect on sukuk rating. Second, Liquidity does not have a significant positive effect on sukuk rating. Third, Leverage has no significant effect on sukuk rating. The study also can be clonclude that based on simultaneous test, the variables of profitability, liquidity, leverage, and company size have a significant effect on sukuk ratings simultaneously.

\section{Recommendations}

The next study can add other variables that can potentially be used to influence sukuk ratings. The sample only uses corporate companies ranked by PT. PEFINDO during the 2014-2017 period, so that the grace period needs to be added longer in order to get more robust study.

\section{References}

1. A. Juliantri and Rasmini, Udayana J. Account. (2013)

2. A. Purwaningsih, Kinerja 12, 85 (2017)//Purwaningsih, Anna. 2008. Pemilihan rasio keuangan terbaik untuk memprediksi peringkat obligasi: studi pada perusahaan manufaktur yang terdaftar di BEJ, Jurnal:Kinerja, Volume 12, No. 1, Tahun 2008.

3. A. T. Kurniawan and T. Suwarti, Pros. Semin. Nas. Multi Disiplin Ilmu \&Call Pap. Unisbank Ke-3 3, 435 (2017)

4. Brigham \& Houstan, Dasar-Dasar Manajemen Keuangan, 11th ed. (Salemba Empat, Jakarta, 2013)

5. D. F. J. 2011 KEOWN, ARTHUR, MARTIN, JHON D, PETTY, J. WILLIAM, SCOTT, J. Chem. Inf. Model. 53, 1689 (2011)

6. D. Kustiyaningrum, E. Nuraina, and A. L. Wijaya, Assets J. Akunt. Dan Pendidik. 5, 25 (2017)

7. E. Pranoto, R. Anggraini, and E. Takidah, J. Wahana Akunt. 12, 13 (2017)

8. E. S. Utami, D. Anitasari, and T. Endhiarto, Rev. Manag. Entrep. 1, 27 (2017)

9. $\quad$ E. W. S. N. Kartika Hendra Titisari, J. Akunt. DAN PAJAK 18, (2017)

\section{FATWA DSN-MUI No.32/DSN-MUI/IX/2002, tentang Obligasi Syariah}

11. H. J. Sihombing and E. N. Rachmawati, J. Ekon. Manaj. Dan Akutansi Vol 1 No 1, 95 (2015)//Sihombing dan Eka Nuraina Rachmawati. 2015. Faktor-faktor yang mempengaruhi peringkat sukuk pada perusahaan yang terdaftar di bursa efek Indonesia. Jurnal Ekonomi. Manajemen dan Akuntansi 1 Vol 24 no 1 
12. I Made Sudana, Manajemen Keuangan Teori Dan Praktik (Airlangga University Press, Surabaya, 2009)

13. I. Fahmi, Analisis Laporan Akuntansi. Bandung: ALFABETA. (2011)

14. I. Ghozali, Aplikasi Analisis Multivariate Dengan Program IBM SPSS 21 :Update PLS Regresi, Edisi 8. (Badan Undip, Semarang, 2013)

15. I. Wijayanti and M. P. Priyadi, J. Ilmu Dan Ris. Akunt. 3, (2014)

16. J. Hartono, Sol. Energy Res. (2013) // Hartono, J. 2013. Teori Portofolio dan analisis investasi, Edisi kedelapan, BPE, Yogyakarta. http://studyclubiainkendari.wordpress.com/2016/12/23/analisis-perkembangansukuk-si-indonesia/)

17. J. Jusuf, Analisis Kredit: Untukcredit (Account) Officer (PT Gramedia Pustaka Utama, Jakarta, 2014)

18. K. O. Tensia, R. Yaya, and E. Supriyono, JBTI J. Bisnis Teor. Dan Implementasi Vol. 6, 184 (2015)

19. M. A. A. Elhaj, N. A. Muhamed, and N. M. Ramli, Procedia Econ. Financ. 31, 62 (2015)

20. M. Martinus and R. Suryaningsih, J. Ultim. Account. 6, 56 (2014)

21. Ma'arij, Arinutry, Zulbahridar, dan Al Azhar. 2014. Analisis Faktor Akuntansi Dan Non Akuntansi Yang Mempengaruhi Prediksi Peringkat Obligasi Pada Perusahaan Non Keuangan Yang Terdaftar Di BEI Dan Di Peringkat oleh Pefindo periode 2009-2013.Jom FEKON (online) Vol. 1 No. 2

22. Mardiah, Gina. Malik, Zaini Abdul dan Nurdin. 2016. Pengaruh Likuiditas, profitabilitas dan Leverage terhadap Peringkat Sukuk (Penelitian Terhadap perusahaan-perusahaan yang Menerbitkan Sukuk Terdaftar di Bursa Efek Indonesia Selama periode 2009-2014).Prosiding Keuangan dan Perbankan Syariah. 2460-6561

23. Nurhayati dan Wasiah, Akuntansi Syariah Di Indonesia (Salemba Empat, Jakarta, 2015)

24. Praptiningsih. 2015. Pengaruh profitabilitas dan likuiditas serta ukuran perusahaan terhadap peringkat sukuk. Bina Widya. Volume 26 Nomor 4, Edisi Oktober 2015,199-208.

25. R. K. Sari, S. Nurlaela, and K. H. Titisari, 2nd International Conference on Technology, Education and Social Science 2018, 418 (2018)

26. R. M. E. Sabeni, Arifin Dwiyanti, Diponegoro J. Account. 3, 716 (2014)

27. Sugiyono, Metode Penelitian Manajemen (Alfabeta, Bandung, 2014) 
28. T. Darmadji and Fakhruddin, Pasar Modal Indonesia : Pendekatan Tanya Jawab, 3rd ed. (Salemba Empat, Jakarta, 2012).

29. Yohanes, Andrey, 2012. Pengaruh rasio keuangan dan karakteristik obligasi terhadap rating obligasi korporasi di Indonesia. Artikel penelitian publikasi:http://bati.imtelkom.ac.id/pustaka/files/16237/jurnal/pengaruh-rasio-

keuangan-dan -karakteristik-obligasi-terhadap-rating-obligasi-korporasi-diindonesia.pdf,diakses pada 20 juni 2015

30. Yulianingsih, G 2013. “Analisis faktor-faktor yang mempengaruhi prediksi peringkat obligasi pada perusahaan yang listing di BEI", Jurnal Manajemen S1 Universitas Andalas, Vol. 1, No, 1, halaman 1-11. 